\section{Scientific journal}

\section{PHYSICAL AND MATHEMATICAL EDUCATION}

Has been issued since 2013.

Науковий журнал

ФІЗИКО-МАТЕМАТИЧНА ОСВІТА

Видається з 2013.
ISSN 2413-158X (online)

ISSN 2413-1571 (print)

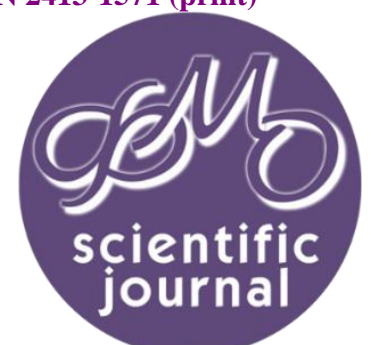

Мар'єнко М.В., Носенко Ю.Г., Шишкіна М.П. Засоби і сервіси європейської хмари відкритої науки для підтримки науково-освітньої діяльності. Фізико-математична освіта, 2021. Випуск 5(31). С. 60-66.

Marienko M., Nosenko Yu., Shyshkina M. Tools and services of the european open science cloud in order to support scientific and educational activities. Physical and Mathematical Education, 2021. Issue 5(31). P. 60-66.

DOI 10.31110/2413-1571-2021-031-5-009

удк 378.046.4

М.В. Мар'єнко

Інститут інформаційних технологій і засобів навчання НАПН України, Україна popelmaya@gmail.com https://orcid.org/0000-0002-8087-962X

Ю.Г. Носенко

Інститут інформачійних технологій і засобів навчання НАПн України, Україна nosenko-y@ukr.net https://orcid.org/0000-0002-9149-8208

М.П. Шишкіна

Інститут інформаційних технологій і засобів навчання НАПн України, Україна marimodi@gmail.com https://orcid.org/0000-0001-5569-2700

\title{
ЗАСОБИ І СЕРВІСИ ЄВРОПЕЙСЬКОї ХМАРИ ВІДКРИТОЇ НАУКИ ДЛЯ ПІДТРИМКИ НАУКОВО-ОСВІТНЬОї ДІЯЛЬНОСТІ
}

АНОТАЦІЯ

В статті проаналізовано сучасні тенденції європейського простору відкритої науки, сутність і переваги хмаро орієнтованих засобів і сервісів відкритої науки. Розглянуто приклади сервісів Європейської хмари відкритої науки. Надано рекомендації щодо якісного й ефективного запровадження засобів і сервісів відкритої науки в науково-освітню діяльність.

Формулювання проблеми. Актуальність роботи обумовлена необхідністю покращення якості та результативності впровадження в науково-освітню діяльність засобів і сервісів відкритої науки, підвищення ефективності їх використання у вітчизняній науці та системі освіти, поліпшення рівня підготовки фахівців освітньої галузі, зокрема вчителів.

Матеріали і методи. Для розв'язування поставлених у роботі завдань використано теоретичні методи: аналіз науковопедагогічних теорій та концепцій з проблеми дослідження; аналіз та узагальнення тенденцій європейського простору відкритої науки; аналіз функціоналу хмаро орієнтованих сервісів відкритої науки.

Результати. Розглянуто сутність поняття хмаро орієнтованої системи відкритої науки. Проаналізовано сутність і значення Європейської хмари відкритої науки. Визначено основні тенденції, що наразі превалюють в Європейському просторі відкритої науки: відкритий доступ, архівування статей, обмін даними. Розглянуто приклади сервісів Європейської хмари відкритої науки. Надано рекомендації щодо запровадження засобів і сервісів відкритої науки в науково-освітню діяльність.

Висновки. Врахування сучасних тенденцій європейського простору відкритої науки, використання переваг хмаро орієнтованих засобів і сервісів відкритої науки з урахуванням авторських рекомендацій сприятиме покращенню якості, ефективності та результативності науково-освітньої діяльності у вітчизняних закладах науки й освіти, ерективності впровадження в освітній процес засобів і сервісів хмарних обчислень, ширшому використанню сервісів відкритої науки на різних рівнях навчання, поліпшенню рівня підготовки фахівців освітньої галузі.

КЛЮчОвІ СЛОвА: відкрита наука, засоби і сервіси відкритої науки, Європейська хмара відкритої науки, науково-освітня діяльність, тендениії.

ВСТУП

Постановка проблеми. В умовах глобалізації, євроінтеграції, прискореної цифрової трансформації багатьох сфер діяльності людини виникає потреба покращенні конкурентоспроможності освітньої сфери України, формування сучасних компетентностей і кваліфікацій людини, підвищення рівня доступності та якості освіти. Як зазначають представники SiS.net

(C) М.В. Мар’єнко, Ю.Г. Носенко, М.П. Шишкіна, 2021 
(проєкту в межах Рамкової програми Європейського Союзу з досліджень та інновацій «Горизонт 2020»), наразі в Європі спостерігається дефіцит науко-орієнтованих, «науково-знаючих» осіб на всіх рівнях діяльності суспільства та економіки. Ключовим чинником підготовки таких осіб, здатних адаптуватися до динамічних суспільно-економічних змін, критично мислити, ефективно вирішувати фахові і повсякденні задачі із залученням сучасних технічних досягнень і технологічних цифрових рішень, займатися сталим саморозвитком, бути успішними в обраній професії і т.д. $€$ кооперація зусиль вмотивованих, кваліфікованих фахівців науково-освітньої сфери - педагогічних, науково-педагогічних, наукових кадрів (Мар'єнко\&Шишкіна, 2020).

Однією із основних умов поліпшення якості підготовки фахівців науково-освітньої сфери, підвищення рівня їх професійної компетентності, ширшого використання інноваційних педагогічних технологій, розширення частки дослідницького підходу у навчанні $\epsilon$ запровадження хмаро орієнтованих сервісів і технологій відкритої науки у закладах вищої педагогічної, післядипломної педагогічної освіти. Наразі проблеми проєктування і використання хмаро орієнтованих сервісів і технологій відкритої науки в науково-освітній діяльності належать до першочергових в аспекті цифровізації. Хмаро орієнтовані системи відкритої науки нового покоління, що $є$ більш гнучкими, потужними, функціональними, привертають все більшу увагу дослідників. їх запровадження має позитивно позначитися на якості науково-освітньої діяльності, забезпеченні ширшого доступу до перспективних IKT, розширенні частки дослідницького підходу в навчанні, підвищенні якості наукових досліджень та освітніх послуг (Мар'єнко\&Шишкіна, 2020).

Це потребує обгрунтування теоретико-методологічних засад створення хмаро орієнтованих систем відкритої науки у закладах освіти, дослідження інноваційних моделей, принципів і методів їх формування і використання, визначення найбільш доцільних шляхів впровадження. Необхідно взяти до уваги світові тенденції, що полягають у переході до масового впровадження у закладах освіти науково-освітніх платформ і інфраструктур відкритої науки, зокрема, сервісів Європейської хмари відкритої науки (European Open Science Cloud, EOSC), що дозволяє створити нову високо потужну інформаційно-технологічну екосистему організації освітньо-наукового процесу.

3 огляду на значний педагогічний потенціал і новизну існуючих підходів до проєктування хмаро орієнтованих систем відкритої науки, їх формування і використання у закладах освіти, ці питання ще потребують теоретичних та експериментальних досліджень, уточнення підходів, моделей, методів і методик, можливих шляхів впровадження. Актуальність роботи обумовлена необхідністю покращення якості та результативності впровадження в науково-освітню діяльність засобів і сервісів відкритої науки, підвищення ефективності їх використання у вітчизняній науці та системі освіти, поліпшення рівня підготовки фахівців освітньої галузі, зокрема вчителів.

Аналіз актуальних досліджень. В останні роки в Україні реалізовано кілька міжнародних проєктів, присвячених питанням реалізації пріоритетів відкритої науки у закладах освіти. Зокрема, з 2016 року реалізується проєкт «Громадська синергія: посилення участі громадськості в євроінтеграційних реформах». В межах цього проєкту здійснювалась цілеспрямована аналітична та інформаційно-просвітницька діяльність задля більшої ефективності формування громадянського суспільства і участі в євроінтеграційних процесах. У 2017-2020рр. здійснювався міжнародний освітній проєкт DocHub, присвячений структуризації співпраці щодо аспірантських досліджень, навчання універсальних навичок та академічного письма на регіональному рівні України. В межах цього проєкту була розроблена навчальна програма «Відкрита наука», спрямована на формування навичок відкритої науки у аспірантів, що впроваджувалась в освітній процес пілотних закладів (Мар'єнко \& Шишкіна, 2020).

R. Farrow, R. Pitt, та M. Weller в своєму дослідженні представили проект «Відкритий підручник Великобританії» (Farrow, Pitt\&Weller, 2020) та окреслили фактори його успіху щодо просування відкритої науки та відкритої педагогіки. Тобто дослідники розглядають поряд з терміном «відкрита наука» ще й термін «відкрита педагогіка». Підручники залишаються основною складовою освітнього забезпечення науки, вважають науковці R. Farrow, R. Pitt, та M. Weller. Відкриті підручники - це відкриті ліцензовані академічні підручники, у яких електронна версія доступна у вільному доступі, а друкована - за зниженою вартістю. Вони є формою відкритого освітнього ресурсу. В останні роки ряд підручників 3 відкритою ліцензією продемонстрували високий вплив у таких країнах, як США, Канада та ПАР. Проект "Відкриті підручники Великобританії" мав пілотне впровадження (з акцентом на теми STEM) у контексті Великобританії у період з 2017 по 2018 рік. Проект одну з основних цілей: сприяти поширенню відкритих підручників у Великобританії. Завдяки низці семінарів у ряді ЗВО та цілеспрямованому просуванні на конкретних освітніх конференціях проект успішно підняв популярність відкритих підручників у Великобританії. Кілька тематичних досліджень повідомляють про наявні приклади використання відкритих підручників у науці Великобританії. Серед британських науковців був значний інтерес та зацікавленість до відкритих підручників. Частково це було пов'язано з економією коштів для студентів, але більш вагомими факторами були свобода адаптувати та розробляти підручники та відкриті електронні ресурси. Це узгоджується з рядом досліджень, що проводилися в інших країнах, і свідчить про те, що потенціал впливу на британську наукову освіту є великим (Farrow, Pitt\&Weller, 2020).

Що ж стосується поняття «відкритої педагогіки», то для розкриття його змісту краще звернутись до роботи A. Wesolek, J. Lashley, A. Langley (Wesolek, Lashley\&Langley, 2018). По суті, відкрита педагогіка описує втручання, спрямоване на покращення викладання та навчання. Натомість відкрита педагогіка представляє бачення освіти, яке замінює аудиторії контролю спільнотами можливостей. Саме тому педагоги прагнуть розширити можливості студентів та викладачів, розширити їх свободу вибору та доступ до високоефективних освітніх практик. Відкрита педагогіка невід'ємна частина сучасного руху за відкриту освіту (Wesolek, Lashley\&Langley, 2018).

Досліджуючи відкриту науку слід проаналізувати дослідження присвячені Європейській хмарі відкритої науки. В дослідженні E. Sciacca (Sciacca et al, 2020) Європейська хмара відкритої науки (EOSC) представлена як федеративне середовище для розміщення та обробки даних досліджень для підтримки науки у всіх дисциплінах без географічних кордонів, таким чином, щоб дані, програмне забезпечення, методи та публікації могли бути представлені як частина спільноти відкритої науки. У роботі (Sciacca et al, 2020) представлено поточну діяльність, пов'язану із впровадженням послуг візуальної аналітики, інтегрованих у EOSC, для вирішення різноманітних потреб спільнот користувачів астрофізики 
щодо управління даними, картографування та виявлення структур. Ці послуги спираються на візуалізацію для управління процесом життєвого циклу даних згідно з принципами FAIR, iнтегруючи обробку даних для створення зображень та створення багатовимірної мапи, а також, застосовуючи методи машинного навчання, для виявлення структур у масштабних багатовимірних мапах.

У вітчизняному освітньому просторі здійснюються заходи щодо запровадження хмарних технологій відкритої науки. Зокрема, ці питання знаходять своє місце у тематиці щорічного міжнародного семінару “Хмарні технології в освіті» (Інститут інформаційних технологій і засобів навчання НАПН України, з 2012 р.), у діяльності спільних науково-дослідних лабораторій з проблем використання хмарних технологій в освіті (Інститут інформаційних технологій і засобів навчання НАПН України, Криворізький національний університет, Тернопільський національний педагогічний університет імені Володимира Гнатюка, Житомирський державний університет, Переяслав-Хмельницький державний педагогічний університет імені Григорія Сковороди) та ін. Тим часом, нові підходи і технології потребують масового впровадження і використання, особливо у процес підготовки вчителів. Науково-методичне опрацювання цього процесу залишається в Україні нині практично відсутнім (Мар'єнко\&Шишкіна, 2020).

Мета статті. Надати рекомендації щодо якісного й ефективного запровадження засобів і сервісів відкритої науки в науково-освітню діяльність шляхом аналізу сучасних тенденцій європейського простору відкритої науки, сутності і переваг хмаро орієнтованих засобів і сервісів відкритої науки.

\section{МЕТОДИ ДОСЛІДЖЕННЯ}

Для розв'язування поставлених у роботі завдань використано теоретичні методи: аналіз науково-педагогічних теорій та концепцій з проблеми дослідження за авторством вітчизняних і закордонних дослідників, експертів у галузі відкритої науки, суспільства знань; аналіз та узагальнення тенденцій європейського простору відкритої науки, вітчизняних та закордонних підходів до організації науково-освітньої діяльності з використанням хмаро орієнтованих систем відкритої науки; аналіз функціоналу хмаро орієнтованих сервісів відкритої науки, можливостей їхнього застосування в науковоосвітній діяльності та ін.

У статті подано результати другого етапу проєкту «Хмаро орієнтовані системи відкритої науки у навчанні $\mathrm{i}$ професійному розвитку вчителів» (2020.02/0310), що фінансується Національним фондом досліджень України. Автори статті є виконавцями даного проєкту.

Розв'язання завдань, поставлених у науковому дослідженні, мають відповідати вимогам сучасних досліджень в галузі освіти і науки; сучасним тенденціям розвитку інформаційного суспільства та впровадження інформаційнокомунікаційних технологій в освіту; системному підходу до наукових досліджень; містити новітні дані та нову інформацію, корисну для дослідників, наукових і науково-педагогічних працівників щодо використання хмаро орієнтованих систем відкритої науки у своїй професійній навчальній діяльності на наукових дослідженнях; враховувати потреби цифровізації закладів освіти; базуватися на кращих практиках застосування IKT в науково-освітньому процесі.

\section{РЕЗУЛЬТАТИ ДОСЛІДЖЕННЯ}

Розвиток науково-освітнього середовища характеризується поширенням більш гнучких, персоніфікованих, відкритих організаційних систем, що стає можливим із використанням хмаро орієнтованих засобів і сервісів. Залучення у практику роботи сучасних закладів освіти хмарних технологій відкритого наукового й інформаційно-освітнього простору також може відіграти провідну роль щодо: поглиблення зв'язків освіти, науки і виробництва, розширення співпраці навчальних і наукових установ, створення різноманітних структур корпоративного характеру, підтримуваних засобами хмарних технологій, спрямованих на розвиток більш тісної взаємодії з сектором вищої освіти, розв'язання нагальних соціальних і економічних проблем, поліпшення інтенсивності наукового пошуку й процесу підготовки кадрів тощо.

Формування і підтримування в актуальному стані мережних електронних інформаційних ресурсів, засобів і сервісів відкритого науково-освітнього середовища можна досягти шляхом запровадження цифрових інструментів відкритої освіти (Методологія формування хмаро орієнтованого навчально-наукового середовища педагогічного навчального закладу, 2017), серед яких:

- науково-освітні інформаційні мережі;

- віртуалізовані системи підтримування навчальної взаємодії;

- хмаро орієнтовані корпоративні інформаційні системи і сервіси, у яких передбачено доступ групи користувачів до гнучко організованого пулу електронних освітніх ресурсів;

- системи підтримування дистанційного навчання;

- інформаційно-аналітичні мережні системи підтримування наукових досліджень (електронні журнальні системи, е-бібліотеки, системи веб-конференцій та ін., що розміщенні на хмарних серверах або постачаються як сервіс);

- системи управління проєктами;

- засоби проектування електронних освітніх ресурсів;

- спеціалізоване програмне забезпечення, що постачається як сервіс (сервіси математичного призначення, конструювання, проєктування, візуалізації і подання даних, статистичного опрацювання результатів, семантичного і синтаксичного аналізу текстів та ін.).

Із поширенням хмаро орієнтованих рішень, змінюються способи організації доступу до електронних ресурсів, змінюються їх структура і функції, урізноманітнюються форми діяльності з ними. Концептуальною відмінністю даного підходу є те, що не лише ресурси, але й сервіси є віртуальними, існують «в хмарі», що створює сприятливі умови для ширшого доступу до різних типів сервісів.

Під хмаро орієнтованими системами відкритої науки розуміємо сукупність хмарних сервісів, розміщених на єдиній платформі і пов'язаних один з одним інструментарієм, адаптованим під потреби проєктування і розгортання відкритих систем навчання і наукових досліджень. До них відносимо (рис. 1): 
- системи підтримування діяльності віртуальних навчальних/наукових колективів, що забезпечують доступ до гнучко організованого пулу електронних ресурсів;

- інформаційно-аналітичні мережні системи і сервіси підтримування наукових досліджень (електронні журнальні системи, е-бібліотеки, системи веб-конференцій та ін., що розміщенні на хмарних серверах або постачаються як сервіс);

- системи підтримування навчальних/наукових проєктів;

- спеціалізоване програмне забезпечення, що постачається як сервіс (сервіси математичного призначення, конструювання, проектування, візуалізації і подання даних, статистичного опрацювання результатів, семантичного і синтаксичного аналізу текстів та ін.);

- дослідницькі наукові мережі й інфраструктури, Європейська хмара відкритої науки та інші.

Хмаро орієнтовані системи відкритої науки - гнучкі, потужні, функціональні засоби, розвиток і запровадження яких має позитивно позначитися на забезпеченні ширшого доступу до перспективних інформаційних технологій, розширенні частки дослідницького підходу у навчанні, реалізації всіх складників відкритої науки (рис. 1), підвищенні якості наукових досліджень і освітніх послуг загалом.

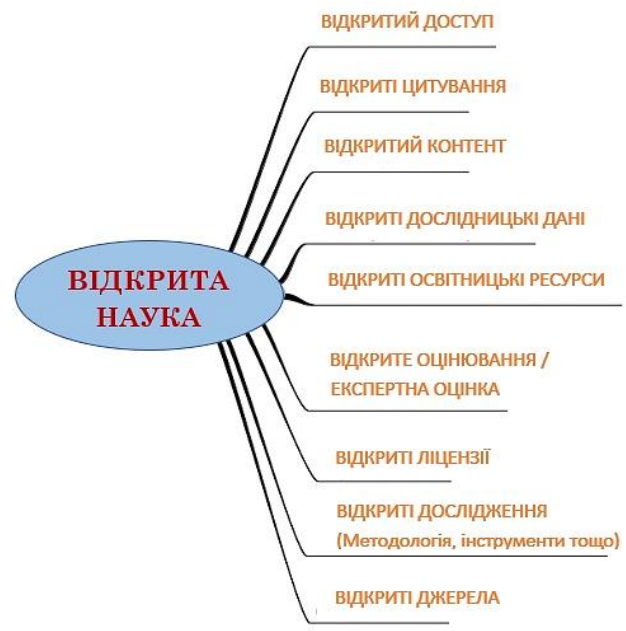

Рис. 1. Складники відкритої науки (Baumgartner, 2019)

Сервіси Європейської хмари відкритої науки. У європейському просторі бачення глобальної відкритої науки реалізується через амбітну програму - Європейську хмару відкритої науки (European Open Science Cloud (EOSC), 2018 р.). Ідея зі створення EOSC була запропонована в 2016 році за ініціативою Європейської комісії, як частина Європейської хмарної ініціативи (European Cloud Initiative) для побудови конкурентоспроможної економіки даних та знань у Європі. Нині EOSC спрямована на розвиток інфраструктури, що надає своїм користувачам послуги, які сприяють розвитку відкритих наукових практик. Іншими словами, портал EOSC $€$ «точкою збору» для сервісів, пропонуючи розподілені хмаро орієнтовані ресурси, що дозволяють дослідникам та ін. обробляти і аналізувати дані у розподіленому цифровому середовищі, мати доступ до публічних і комерційних сервісів електронної інфраструктури на національному, регіональному та інституційному рівнях.

Запровадження EOSC віддзеркалює основні тенденції, що наразі превалюють в Європейському просторі відкритої науки, зокрема:

- відкритий доступ. Кількість публікацій у відкритому доступі щорічно зростає. Наразі майже 2/3 авторів зазначають, що вони опублікували статтю в журналі з гібридним або золотим доступом. Це - на 8\% вище, у порівнянні $з$ 2013 p.;

- архівування статей. В останні роки архівування статей у кількісному відношенні зросло вдвічі, шляхом розміщення їх в інституційних та публічних сховищах, на особистих веб-сторінках тощо. Головними причинами активізації стали вимоги закладів до своїх співробітників та прагнення останніх до поширення результатів досліджень.

- обмін даними. Згідно з дослідженням (Vocile, 2017) 2017, 69\% опитаних учених зазначили, що вони певним чином ділилися, обмінювалися даними своїх досліджень, що на 17 \% більше, порівняно з результатами опитування 2014 р. Найпоширенішими формами обміну даними виявилися такі: конференції (48 \%), додатки до статей (40 \%), за запитом або при неформальному спілкуванні (33 \%). Тільки 20 \% респондентів відзначили, що оприлюднювали результати досліджень через формальні, інституційні репозитарії, що, тим не менш, на 7 \% вище, ніж два роки тому. Серед причин того, чому окремі науковці не бажають поширювати дані своїх досліджень, наголошують на питаннях інтелектуальної власності та конфіденційності, висловлюють стурбованість етичними питаннями, острахом зловживань та неправомірних запозичень з боку читачів.

У перспективі, Європейська хмара запропонує 1,7 мільйону європейських дослідників та 70 мільйонам професіоналів у галузі науки, техніки, гуманітарних та соціальних наук віртуальне середовище 3 відкритими безперебійними сервісами для зберігання, управління, аналізу та повторного використання дослідницьких даних шляхом об'єднання існуючих наукових інфраструктур даних, що в даний час розподілені між державами-членами ЄС.

На рис. 2 представлено архітектуру сервісів EOSC, або класи сервісів, що вже існують, або які планують запровадити. Питання щодо подальшого розвитку вже існуючих сервісів, створення нових сервісів, забезпечення їхньої надійності та сумісності $€$ на часі і належать до пріоритетів ініціаторів Європейської хмари.

До прикладу, розглянемо окремі сервіси, що наразі представлені в EOSC. 


\section{Сервіси загально наукового призначення.}

Infrastructure Manager (IM) - це служба з відкритим кодом, яка дозволяє розгортати складну та індивідуальну віртуальну інфраструктуру на кількох серверних пристроях, автоматизувати розгортання, налаштування, встановлення програмного забезпечення, моніторинг та оновлення віртуальних інфраструктур. Підтримує широкий спектр загальнодоступних та локальних хмарних серверів, завдяки чому користувацькі програми є хмарними. Крім того, IM надає можливості DevOps, засновані на Ansible, що дозволяє встановлювати та налаштовувати всі необхідні користувачеві програми, забезпечуючи його багатофункціональною інфраструктурою.

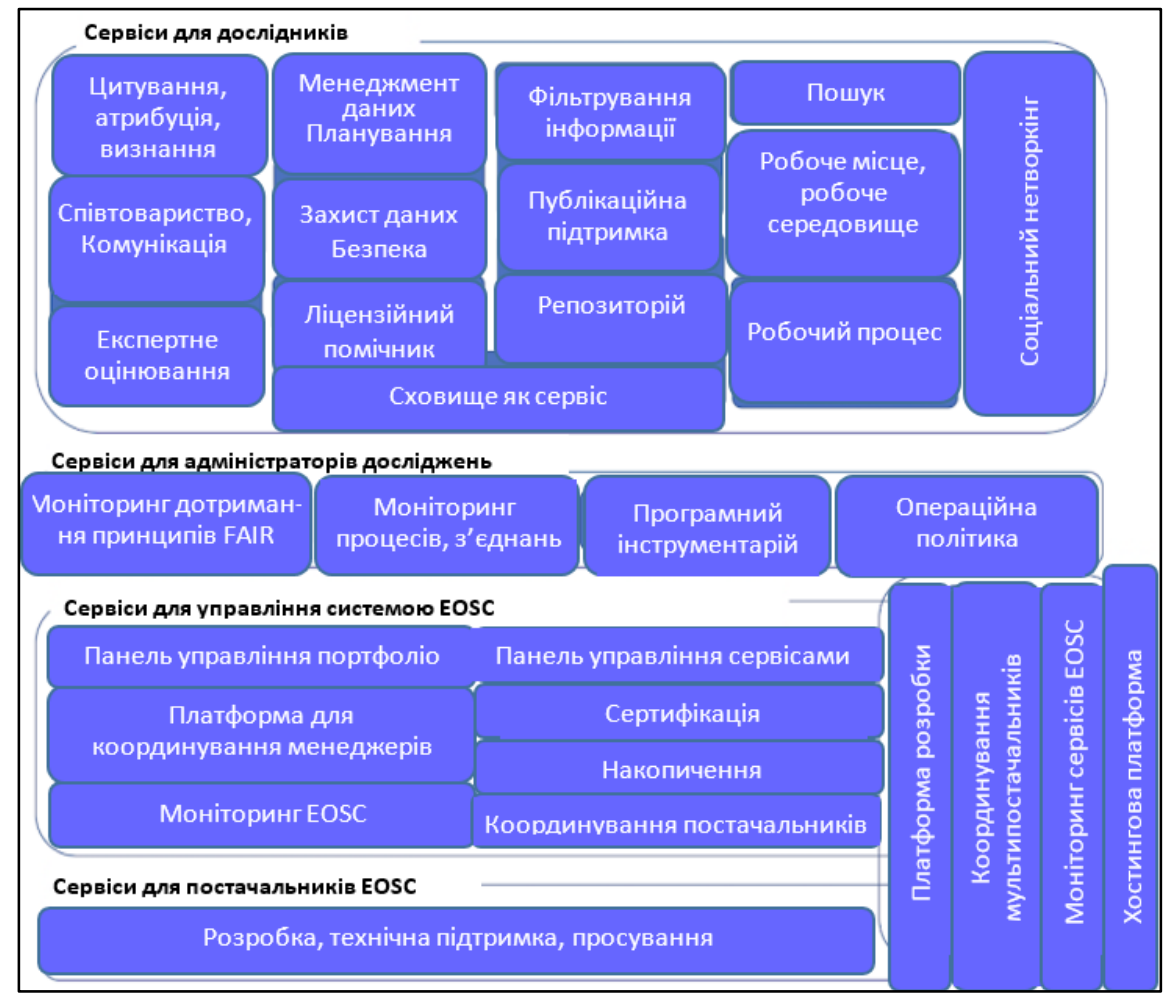

Рис. 2. Архітектура сервісів Європейської хмари відкритої науки (Pioneering Blueprint Delivered for EOSC Service Architecture, 2019)

Серед основних особливостей IM:

- Multi-Backend (розгортання на локальних, загальнодоступних та наукових хмарах і платформах).

- Розширені плагіни, доступні для OpenNebula, Amazon EC2, Google Cloud Platform, Microsoft Azure, Docker, Kubernetes, FogBow, T-Systems OTC, OpenStack, CloudStack ta EGI Federated Cloud (OCCI).

- Гібридні інфраструктури - розгортання віртуальних інфраструктур, що охоплюють кількох провайдерів.

- DevOps на основі Ansible, що дозволяє встановлювати та налаштовувати необхідні програми (наприклад, кластери Hadoop тощо).

- Інтерфейси, включаючи CLI, веб-графічний інтерфейс, сервісний API XML-RPC та REST API.

Дослідницький граф OpenAIRE дозволяє розробникам створювати сервіси для наукової комунікації та дослідницької аналітики. За допомогою API, користувач отримує доступ до графа OpenAIRE - графа наукової комунікації, тобто цифрового простору, в якому можна знайти інформацію про об'єкти життєвого циклу наукової комунікації (публікації, дані досліджень, програмне забезпечення для підтримки досліджень, проєктів, організації тощо) та про семантичні зв'язки між ними. Доступ до графа OpenAIRE надається за низкою протоколів (OAI-PMH, HTTP API, SPARQL), щоби задовольнити потреби розробників незалежно від їхніх вимог і вподобань.

Граф OpenAIRE оновлюється раз на два місяці шляхом:

- агрегування метаданих з європейської та глобальної мережі OpenAIRE, що містить надійні дані і ресурси; перевірених джерел даних OpenAIRE;

- збагачення метаданих через додавання в опис ресурсів повнотекстових результатів і висновків;

- збору метаданих від кінцевих користувачів за допомогою сервісу EXPLORE: включення в граф відгуків користувачів у вигляді джерела даних.

Графік доступний у виробничій та бета-версії.

Сервіси підтримки фізичних наук.

Cepвic Astronomical Online Data Analysis (AstroODA). Сервіс дозволяє користувачам здійснювати обробку і аналіз хмаро орієнтованих наукових даних астрофізичних обсерваторій та експериментів, забезпечуючи надійні результати. У цей час немає іншої державної служби, яка забезпечує цю функцію. Наразі відсутні відкриті сервіси, що надавали б у повній мірі аналогічну функціональність.

Репозиторій NOMAD (Novel Materials Discovery (NOMAD) Repository) - найбільше у світі зібрання даних з матеріалознавства. Для обчислювального моделювання та дослідження сучасних матеріалів і їх застосування 
застосовується складне спеціалізоване програмне забезпечення. Це забезпечує розуміння властивостей матеріалів, розробку нових матеріалів, які відповідають конкретним вимогам. Репозиторій NOMAD підтримує файли практично всіх форматів, зберігає дані упродовж не менш ніж 10 років, відкритий доступ може бути відкладений терміном до трьох років. За запитом ресурсам присвоюється DOI для покращення цитування. У репозиторії зберігаються повні файли 3 обрахунками, відомості світових баз даних з матеріалознавства.

Сервіси підтримки гуманітарних та освітніх наук.

DA/RA (DOI Registration Service) - сервіс з реєстрації DOI для соціальних наук (присвоєння ідентифікаторів цифровим об'єктам шляхом використання системи DOI (digital object identifier - цифрового ідентифікатора об'єкта)). Реєстрація DOI здійснюється у тісній співпраці з організаціями, що надають дані (архіви даних, дослідницькі data-центри та ін.), відповідають за підтримку і зберігання даних досліджень та метаданих. DA|RA призначає адентифікатори DOI через DataCite, зберігає надані метадані та забезпечує можливість пошуку зареєстрованого контенту в базі даних. Метадані також вільно доступні через протокол ОАІ-PMH (Open Archives Initiative Protocol for Metadata Harvesting - Протокол Ініціативи відкритих архівів для збирання метаданих). DA|RA оперує специфічною схемою метаданих, що відповідає стандарту DDI (Data Documentation Initiative - Ініціативи з документування даних). Окрім цього, інструментарій DA|RA пропонує веб-сервіс (API), що дозволяє працювати автоматично з сервісом реєстрації DOI.

Репозиторій LINDAT/CLARIAH-CZ - відкритий репозиторій, що містить цифрові дані й ресурси з гуманітарних та соціальних наук. Надає платформу для доступу та обміну ресурсами і сучасними інструментами, дозволяє всім користувачам розміщувати, безпечно зберігати та поширювати дані своїх досліджень.

OPERAS Research for Society (Hypotheses) - сервіс з підтримки блогів наукового спрямування в галузі соціальних і гуманітарних наук, орієнтований на вирішення соціальних викликів. OPERAS створений як інтерактивна платформа між дослідниками в галузі соціальних і гуманітарних наук та суспільством, сприяє розвитку практик академічного блогінгу, можливостей побудови відкритої комунікації між учасниками соціально-економічної взаємодії, з акцентом на соціальних викликах.

\section{ОБГОВОРЕННЯ}

Загалом, наразі EOSC налічує понад 300 ресурсів з різних наукових галузей: медичної, інженерії і технологій, природничих наук, генетики, гуманітарних і соціальних наук та ін. Європейська хмара відкритої науки систематично наповнюється новими сервісами для підтримки реалізації концепції відкритої науки в європейському просторі. На часі $\epsilon$ подальший розвиток вже існуючих сервісів, створення нових сервісів, забезпечення їхньої надійності та сумісності, що належать до пріоритетів ініціаторів Європейської хмари.

3 огляду на значний педагогічний потенціал і новизну існуючих підходів до створення, запровадження й використання засобів і сервісів відкритої науки для підтримки науково-освітньої діяльності, ці питання ще потребують теоретичних та емпіричних досліджень, уточнення підходів, моделей, методик, можливих шляхів впровадження.

Врахування сучасних тенденцій європейського простору відкритої науки, використання переваг хмаро орієнтованих засобів і сервісів відкритої науки сприятиме покращенню якості, ефективності та результативності науковоосвітньої діяльності у вітчизняних закладах науки й освіти, ефективності впровадження в освітній процес засобів і сервісів хмарних обчислень, ширшому використанню сервісів відкритої науки на різних рівнях навчання, поліпшенню рівня підготовки фахівців освітньої галузі, зокрема вчителів.

\section{ВИСНОВКИ ТА ПЕРСПЕКТИВИ ПОДАЛЬШОГО ДОСЛІДЖЕННЯ}

На основі здійсненого дослідження сформовано відповідні рекомендації. Отже, для того, щоби реалізувати якісне й ефективне запровадження засобів і сервісів відкритої науки в науково-освітню діяльність необхідно забезпечити:

- поширення інформації стосовно існуючих можливостей, послуг та переваг використання хмарних сервісів, мережних інструментів і платформ відкритої науки, е-інфраструктур та Європейської хмари відкритої науки в процесі навчання і наукових досліджень, науково-освітньої діяльності, запровадження їх в процес підготовки фахівців галузі освіти, в т.ч. вчителів;

- ширше запровадження практик відкритої науки у науково-освітню діяльність, процес навчання і професійного розвитку фахівців галузі освіти, в т.ч. вчителів;

- створення методик розвитку компетентностей різних зацікавлених сторін щодо використання сервісів і технологій відкритої науки і запровадження їх в науково-освітній процес;

- відкритість наукових даних.

3 огляду на значний педагогічний потенціал і новизну існуючих підходів до створення, запровадження й використання засобів і сервісів відкритої науки для підтримки науково-освітньої діяльності, ці питання ще потребують теоретичних та емпіричних досліджень, уточнення підходів, моделей, методик, можливих шляхів впровадження. Зокрема, в якості перспективи подальших досліджень розглядаємо обґрунтування моделей проєктування і використання хмаро орієнтованих систем відкритої науки для підготовки фахівців галузі освіти, в т.ч. вчителів.

\section{Список використаних джерел}

1. Baumgartner P. Open Citations - TOS. 2019. URL: https://notes.peter-baumgartner.net/2019/06/25/open-citations-tos/ (Last accessed: 04.10.2021).

2. Farrow R., Pitt R., Weller M. Open Textbooks as an Innovation Route for Open Science Pedagogy. Education for Information, 2020. Vol. 36, no. 3. Pp. 227-245. DOI: $10.3233 /$ EFI-190260.

3. Pioneering Blueprint Delivered for EOSC Service Architecture. 2019. URL: https://eoscpilot.eu/news/pioneering-blueprintdelivered-eosc-service-architecture (Last accessed: 04.10.2021). 
4. Towards Porting Astrophysics Visual Analytics Services in the European Open Science Cloud / Sciacca E. et al. Intelligent Computing. SAI 2020. Advances in Intelligent Systems and Computing / eds. K. Arai, S. Kapoor, R. Bhatia, 2020. Vol 1230. P. 598-606. DOI: 10.1007/978-3-030-52243-8_43.

5. Vocile B. Open Science Trends You Need to Know About. 2017. URL: https://www.wiley.com/network/researchers/licensingand-open-access/open-science-trends-you-need-to-know-about (Last accessed: 04.10.2021).

6. Wesolek A., Lashley J., Langley A. OER: A Field Guide for Academic Librarians. Pacific University Press, 2018. 468 p. URL: https://open.umn.edu/opentextbooks/textbooks/652 (Last accessed: 04.10.2021).

7. Мар'єнко М. В., Шишкіна М. П. Використання хмаро орієнтованих методичних систем у процесі підготовки вчителів природничо-математичних предметів до роботи в науковому ліцеї. Сучасні інформаційні технології та інноваційні методики навчання у підготовці фахівців: методологія, теорія, досвід, проблеми. Вінниця, 2020. Вип. 56. С. 121-134.

8. Методологія формування хмаро орієнтованого навчально-наукового середовища педагогічного навчального закладу : монографія / Дем'яненко В. М. та ін.; за наук. ред.: М. П. Шишкіної. К.: Педагогічна думка, 2017. 146 с.

\section{References}

1. Baumgartner, P. (2019). Open Citations - TOS. Retrieved from https://notes.peter-baumgartner.net/2019/06/25/opencitations-tos/ [in English].

2. Farrow, R., Pitt, R. \& Weller, M. (2020). Open Textbooks as an Innovation Route for Open Science Pedagogy. Education for Information, 3(36), 227-245. DOI: 10.3233/EFI-190260. [in English].

3. Pioneering Blueprint Delivered for EOSC Service Architecture. (2019). URL: https://eoscpilot.eu/news/pioneering-blueprintdelivered-eosc-service-architecture [in English].

4. Towards Porting Astrophysics Visual Analytics Services in the European Open Science Cloud / Sciacca, E. et al. (2020). Intelligent Computing. SAI 2020. Advances in Intelligent Systems and Computing / Arai, K., Kapoor, S., Bhatia, R. (Ed.), 1230, 598-606. DOI: 10.1007/978-3-030-52243-8_43. [in English].

5. Vocile, B. (2017). Open Science Trends You Need to Know About. Retrieved from https://www.wiley.com/network/researchers/licensing-and-open-access/open-science-trends-you-need-to-know-about [in English].

6. Wesolek, A., Lashley, J., Langley, A. (2018). OER: A Field Guide for Academic Librarians. Pacific University Press. Retrieved from https://open.umn.edu/opentextbooks/textbooks/652 [in English].

7. Marienko, M. V. \& Shyshkina, M. P. (2020). Vykorystannia khmaro oriientovanykh metodychnykh system u protsesi pidhotovky vchyteliv pryrodnycho-matematychnykh predmetiv do roboty $v$ naukovomu litsei [The use of cloud-oriented methodological systems in the process of preparing teachers of natural sciences and mathematics to work in a scientific lyceum]. Suchasni informatsiini tekhnolohii ta innovatsiini metodyky navchannia u pidhotovtsi fakhivtsiv: metodolohiia, teoriia, dosvid, problem - Modern information technologies and innovative teaching methods in training: methodology, theory, experience, problems, 56, 121-134. [in Ukrainian].

8. Demianenko, V. M. Et al (2017). Metodolohiia formuvannia khmaro oriientovanoho navchalno-naukovoho seredovyshcha pedahohichnoho navchalnoho zakladu [Methodology of formation of cloud-oriented educational and scientific environment of pedagogical educational institution] (M. P. Shyshkina). Kyiv: Pedahohichna dumka. [in Ukrainian].

\section{TOOLS AND SERVICES OF THE EUROPEAN OPEN SCIENCE CLOUD IN ORDER TO SUPPORT SCIENTIFIC AND EDUCATIONAL ACTIVITIES \\ Maiia Marienko, Yulia Nosenko, Mariya Shyshkina}

Institute of Information Technologies and Learning Tools of NAES of Ukraine, Ukraine

Abstract. The article analyzes the modern trends of the European space of open science, the essence and benefits of cloud-oriented tools and services of open science. Examples of services of the European Open Science Cloud are considered. Recommendations on qualitative and effective introduction of tools and services of open science in scientific and educational activities are provided.

Problem formulation. The urgency of research is due to the need to improve the quality and effectiveness of the implementation of tools and services of open science in scientific and educational activities, increasing the efficiency of their use in national science and education system, improving the level of training of educational specialists, including teachers.

Materials and methods. Theoretical methods were used to solve the tasks set in the work: analysis of scientific and pedagogical theories and concepts on the research problem; analysis and generalization of tendencies of the European space of open science; analysis of the functionality of cloud-based open science services.

Results. The essence of the concept of a cloud-oriented system of open science is analyzed. The essence and significance of the European open science cloud is considered. The main trends that are currently prevailing in the European space of open science are defined: open access, archiving articles, data sharing. Examples of services of the European open science cloud are considered.

Conclusions. Taking into account the modern trends of the European space of open science, the use of the advantages of cloud-oriented tools and services of open science, taking into account the author's recommendations will contribute to improving the quality and the effectiveness of introduction in the educational process of tools and cloud computing services, wider use of open science services at different levels of study, improving the level of training of specialists of the educational sector.

Key words: Open science, tools and services of open science, European open science cloud, scientific and educational activity, trends.

\section{(cc) $\mathrm{BY}-\mathrm{NC}-\mathrm{SA}$}

This work is licensed under Creative Commons Attribution-NonCommercial-ShareAlike 4.0 International License. 